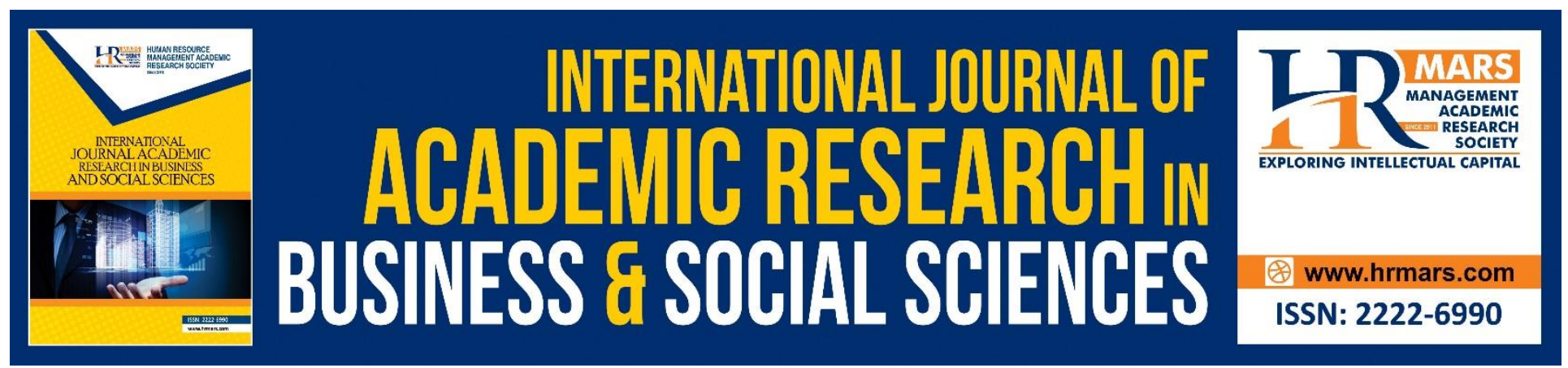

\title{
Firms' Size as a Contingency Approach in the Relationships of Intellectual Capital, Capital Structure and Financial Performance
}

\section{Hapsah S. Mohammad \& Imbarine Bujang}

To Link this Article: http://dx.doi.org/10.6007/IJARBSS/v9-i3/5676

DOI: $10.6007 /$ IJARBSS/v9-i3/5676

Received: 12 Feb 2019, Revised: 08 March 2019, Accepted: 24 March 2019

Published Online: 03 April 2019

In-Text Citation: (Mohammad \& Bujang, 2019)

To Cite this Article: Mohammad, H. S., \& Bujang, I. (2019). Firms' Size as a Contingency Approach in the Relationships of Intellectual Capital, Capital Structure and Financial Performance. International Journal of Academic Research in Business and Social Sciences, 9(3), 268-277.

\section{Copyright: (C) 2019 The Author(s)}

Published by Human Resource Management Academic Research Society (www.hrmars.com)

This article is published under the Creative Commons Attribution (CC BY 4.0) license. Anyone may reproduce, distribute, translate and create derivative works of this article (for both commercial and non-commercial purposes), subject to full attribution to the original publication and authors. The full terms of this license may be seen at: http://creativecommons.org/licences/by/4.0/legalcode

$$
\text { Vol. 9, No. 3, 2019, Pg. } 268 \text { - } 277
$$

Full Terms \& Conditions of access and use can be found at http://hrmars.com/index.php/pages/detail/publication-ethics 


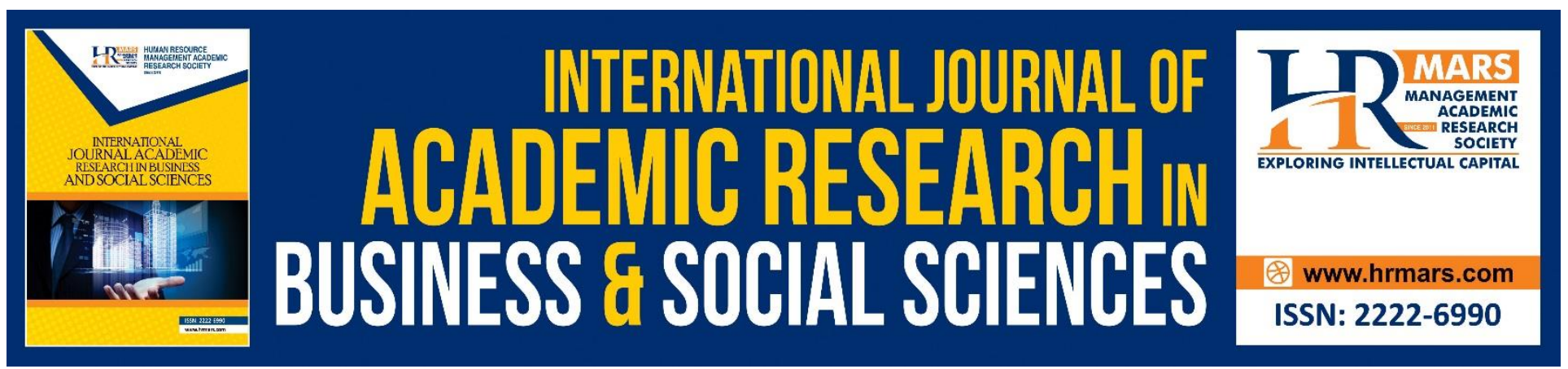

\title{
Firms' Size as a Contingency Approach in the Relationships of Intellectual Capital, Capital Structure and Financial Performance
}

\author{
Hapsah S. Mohammad \\ Senior Lecturer, Faculty of Accountancy, Universiti Teknologi MARA, Kota Kinabalu Campus, Sabah \\ Branch, Locked Bag 71, 88997, Kota Kinabalu, Sabah, \\ Email: hapsahsm@sabah.uitm.edu.my
}

\section{Imbarine Bujang}

Senior Lecturer, Faculty of Business and Management, Universiti Teknologi MARA, Kota Kinabalu Campus, Sabah Branch, Locked Bag 71, 88997, Kota Kinabalu, Sabah, Email: imbar074@sabah.uitm.edu.my

\begin{abstract}
The aim of this study is to examine the influence of firm size on the relationship between intellectual capital, capital structure and financial performance of Malaysian construction firms. The empirical data were taken from 41 construction firms listed in the main board of Bursa Malaysia and observed over the five-year period of 2011 to 2015. This study is deemed necessary as the findings of prior studies on the relationship between intellectual capital, capital structure and financial performance, had documented mixed and inconclusive result, thus, the inclusion of firm size as a moderating variable may modify (strengthen or weaken) the above relationships. Intellectual capital, capital structure, financial performance and firm size are proxy by VAIC Model, total debt ratio, return on equity and log of total asset, respectively. The result shows a positive moderator effect of firm size on the relationship between intellectual capital and financial performance in construction. The findings suggests that firms' value creation capability increases with firms' size, thus larger firms' are in a better position to generate profit. The concentration on one industry and the relatively narrow five-year period for data collection are the main limitations of this study. The findings of the research will contribute towards the literature.
\end{abstract}

Keywords: Firm Size; Contingency Theory; Financial Performance; Moderating Effect. 


\section{Introduction}

Firms' financial performance refer to an environment of how well firms employ their resources, intellectual capital and capital structure, to generate revenues. By measuring financial performance, it reflects on the result of firms' policies and operations in monetary terms. These results are communicated through the firms' return on assets, return on equity, value added. Hence, it is an indicator of firms' financial health over a given period of time. In relation to this, firms' rely on their resources, intellectual capital and capital structure, to create and sustain competitive advantage and ultimately enhance firms' financial performance.

In addition, in the literature of intellectual capital and capital structure, size has long been associated with firms' financial performance. However, most prior studies had minimized the effect of size by making it a control variable. This is due to the fact that their research objectives were to examine purely the relationship either between intellectual capital and financial performance or capital structure and financial performance (Addae, Nyarko-Baasi and Hughes, 2013; Al-Musali and Ku Ismail, 2014). This implies that firms' size has the ability to moderate (strengthen or weaken) the above relationships.

This study concentrated on construction industry as prior literature had indicated that this industry plays an important role in a country's economic development. The industry establishes the infrastructure required for socio-economic development and subsequently contributing to overall economic growth. For this reason, the primary motivation of this study is to extend the understanding of the impact of firms' size on the relationship between intellectual capital, capital structure and financial performance in Malaysia construction industry. The outcome of the study may assist firms' managers to consider the role of firm size in formulating business strategies as different sizes may affect financial performance differently. Therefore, the objective of this paper is to investigate the impact of firms' size on the above relationships.

The remainder of this paper is structured into five parts. Part 2 provides the literature review. Meanwhile, part 3 explains the data and methodology of this study and this is followed by part 4 which outlines the results of the data analysis and discussion of the study. The conclusion and recommendation are presented in part 5.

\section{Literature Review}

Most studies on the relationship between intellectual capital, capital structures and financial performance had treated firms' size as a control variable (Addae et al., 2013; Salim and Yadav, 2012). In a study performed by Addae et al. (2013) on the relationship between capital structure and financial performance, they had included size as a control variable. They argued that the moved was necessary to ensure the accuracy of their results as firm size is not the subject matter of their study. Salim et al. (2012) in their study on the relationship between capital structure and financial performance of Malaysian listed firms controlled the differences in firm's operating environment by including firms' size as a control variable in the model. Firms size were included in the model to control for effects on dependent variable. They argued that the firm's size may influence its 
performance, this is due to the fact that larger firm may have more capacity and capabilities. This suggested that firms' size may moderate the relationship between the independent variables and dependent variable in this study. On another study involving firm's financial performance, using the data from the textile industry of Pakistan, the findings of Abbas, Bashir, Manzuor and Akram (2013) revealed that the firm's performance is significantly affected by its size. The same findings were documented by the study of Safarova (2010) on firm performance of New Zealand listed firms.

Firms' sizes do matter in capital structure decisions. According to Ting and Lean (2011) both theories, trade-off theory and pecking order theory, agree that firms' size is a major determinant of debt. Trade-off theory suggests that larger firms are normally diversified, therefore probability of experiencing bankruptcy is reduced (Karadeniz, Kandir, Balcilar and Onal, 2009). In addition, Morri and Cristanziani (2009) argued that larger firms have better access to capital markets that is they can borrow money at a favorable interest rates. The findings of Marsh (1982) suggested that large firms often choose long-term debt while small firms prefer short-term debt. Therefore, debt increases as a firm's size increases. On the contrary, the findings of Suhaila and Wan Mahmood (2008) revealed that larger firms are less dependent on debt financing than smaller firms. Similar findings were supported by Frank and Goyal (2003), they stated that pecking order theory argues that firms size correlates negatively with debt because information asymmetries are reduced in larger firms. Larger firms are less likely to undervalue new equity issues than smaller firms, thus, larger firms are more likely to use equity financing and lower debt ratio.

In terms of availability of resources, firms size has a role to play. According to Sharma and Kesner (1996) firms' size is a basis of competitive advantage as it contributed towards business survival and variance in operating performance. Therefore, larger firms are more efficient and have better resources to survive economic downturns. On the other hand, Scafarto, Ricci and Scafarto (2016) in his study argued that firm size has an impact on wealth creation due to scale economies and bargaining power.

Based on the arguments presented by previous studies, it leads to the suggestion that firms' size might moderate the relationships between the independent variables and dependent variable. Thus, because of the importance of size from organizational perspective, this study investigates and analyze the moderating impact of size on the relationship between intellectual capital, capital structures and financial performance.

The moderating impact of size on the relationship between intellectual capital, capital structure and financial performance is explained by the contingency theory. The contingency theory of organizational structure provides a major framework for the study of organizational design (Donaldson, 2001). Scott (1992) argued that contingency theory is considered a dominant, theoretical, rational, open system model at the structural level of analysis in organization theory. Daft (1992, p.28) defined contingency as "one thing depends on other things, and for organizations to be effective there must be a "goodness of fit" between their structure and various contingency factors". Contingency theory introduces the concept of "goodness of fit" (Daft, 1992) and according to 
Donaldson (2001) the most effective organizational structural design is where the structure fits the contingencies. Betts (2003) reiterated that a match between the contingencies and the organizational structural design can lead to high performance. This match is called 'fit', the better the fit the higher the performance (Betts, 2003) and size is a major contingency factor that influences organization design and functions (Daft, 1992).

\section{Data and Methodology}

Data was collected from the audited annual reports of construction firms listed in the main board of Bursa Malaysia and the period of analysis is from 2011 to 2015. Initially, this study attempted to take all the firms listed in Bursa Malaysia for construction sector which was 45 firms as at 31 December 2015. However, the actual number of firms subjected to this study was lesser than the initial number proposed because for the firms to be included in the study three criteria will have to be fulfilled (Abor, 2005; Addae et al., 2013). The first criteria is that all the selected firms should have been listed in Bursa Malaysia for the whole five-year period (2011 - 2015), second criteria is that none of the firms have been delisted during the period under investigation and the third criteria is that all the five-year financial statements must be available for all firms to be included in the study. Four firms in construction were dropped due to unavailability of data (failed to meet the three criteria set for this study). Therefore, the data used for the study is based on 205 observations. The research framework of the study is based on two independent variables, one moderating variable and one dependent variable. The two independent variables are intellectual capital and capital structure. The moderating variable is firm size and the dependent variable is financial performance.

This paper is based on the following research framework:

Figure 1: Research Framework

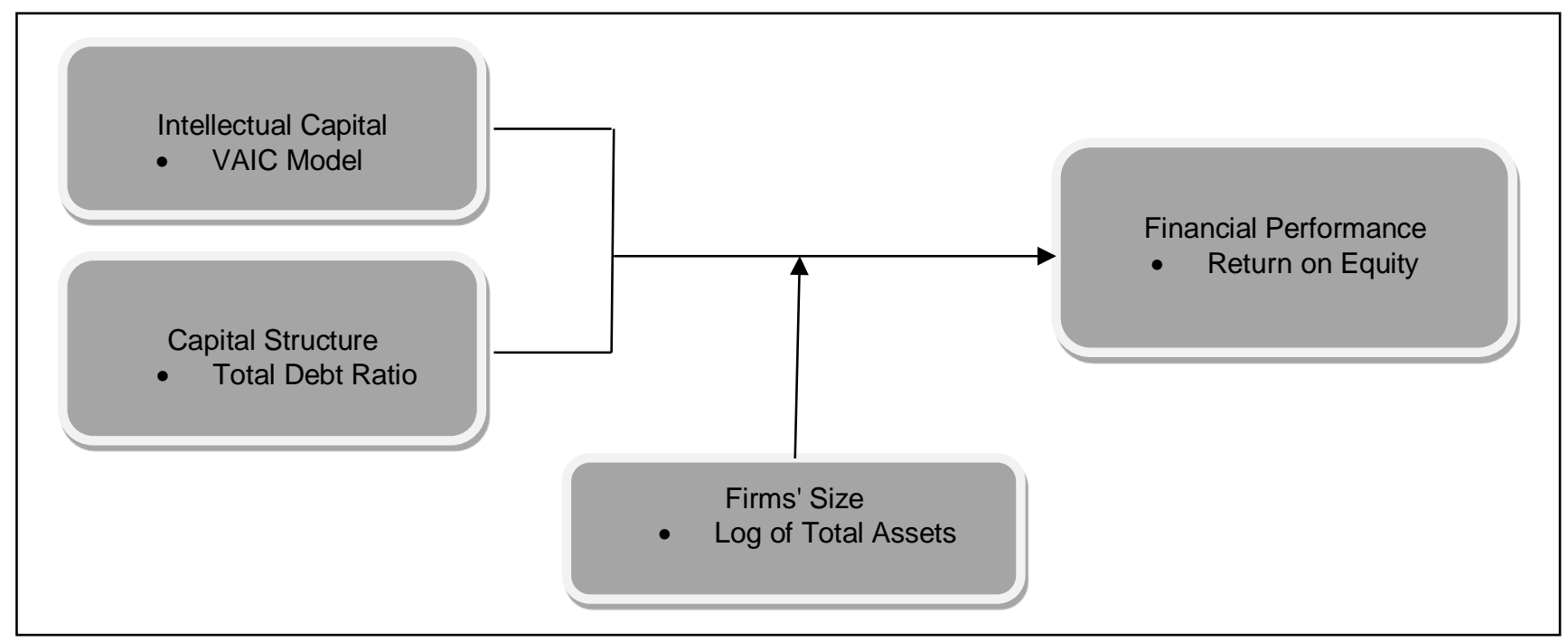

Capital structure is proxy by total debt ratio and is calculated as total debt divided by total assets (Abor, 2005; Nirajini and Priya, 2013; Addae et al., 2013). Intellectual capital is measured using Value-Added 
INTERNATIONAL JOURNAL OF ACADEMIC RESEARCH IN BUSINESS AND SOCIAL SCIENCES

Vol. 9, No. 3, March, 2019, E-ISSN: 222 2-6990 ¿ 2019 HRMARS

Intellectual Coefficient Model (Pulic, 1998) which is based on the equation of VAIC = ICE + CEE, where ICE is intellectual capital efficiency and CEE is capital employed efficiency.

This study adopted ROE as financial performance indicator and is calculated as operating profit divided by equity (share capital and reserves). ROE represents return on equity and it is recognized as an important financial indicator for owners (Al-Musali et al., 2014) and ROE have been commonly used as a key performance indicator of financial performance, thus, it has been robustly tested as a measure of financial performance in earlier researches (Joshi, Cahill, Sidhu and Kansal, 2013). Several indicators had been used in prior studies for firm size such as log of market capitalization (Joshi et al., 2013) and log of total assets. To be consistent with the studies of Ting et al., 2011; Salim et al., 2012; Joshi et al., 2013; Nirajini and Priya, 2013; Al-Musali et al., 2014; Scarfarto et al., 2016, firm size was measured using log of total assets.

The moderating effects of firm size on the relationships between intellectual capital, capital structure and financial performance are hypothesized as follows:

Hypothesis $1(\mathrm{H} 1) \quad$ Size moderates positively the relationship between intellectual capital and financial performance.

Hypothesis 2(H2) Size moderates positively the relationship between capital structure and financial performance.

To test these hypotheses, two regression models were formulated as follows:

Regression Model $1 \quad \mathrm{ROE}_{i \mathrm{t}}=\alpha_{i \mathrm{t}}+\beta_{0} \mathrm{VAIC}_{i \mathrm{t}}+\beta_{1}$ Size $_{i \mathrm{t}}+\varepsilon_{\mathrm{it}}$

Regression Model $2 \quad \mathrm{ROE}_{i \mathrm{t}}=\alpha_{i \mathrm{t}}+\beta_{0} \mathrm{TD}_{\mathrm{it}}+\beta_{1}$ Size $_{i \mathrm{t}}+\varepsilon_{i \mathrm{t}}$

\section{Results and Discussion}

The regression results are presented in table 1 below: 
Table 1: Regression Results

\begin{tabular}{lcc}
\hline Dependent variables: & \multicolumn{2}{c}{ ROE } \\
\hline Independent variables & Model 1 & Model 2 \\
\hline Intercepts & $-348.5426^{* *}$ & $-282.8603^{*}$ \\
& $(-2.23)$ & $(1.77)$ \\
VAIC & $3.499^{* * *}$ & $\mathrm{~N} / \mathrm{A}$ \\
& $(3.68)$ & \\
TD & $\mathrm{N} / \mathrm{A}$ & 0.03511 \\
& & $(0.18)$ \\
Size & $\mathbf{2 6 . 4 3 9 9 * *}$ & $-23.1341^{*}$ \\
& $(\mathbf{2 . 2 9 )}$ & $(1.94)$ \\
\hline $\mathrm{R}^{2}$ & 0.0804 & 0.0189 \\
F-value & 8.83 & 1.95 \\
Sig F-value & $0.0002^{* * *}$ & 0.1456 \\
$\mathrm{~N}$ & 205 & 205 \\
\hline
\end{tabular}

Notes: $* * *, * *, *$ indicate statistical significance at the 1,5 and 10 percent level respectively. The figures in the parentheses are the t-statistics. $\mathrm{N}$ is number of observation. N/A is not applicable.

The reliability of the regression model 1 is tested through the value of $R^{2}$ of 0.0804 and it's F-value of $8.83(p<0.0001)$. These values indicated that 8 percent of possible variation in the ROE is explained by the variables in the model and the model is reliable for prediction. Both variable, VAIC and Size, are positively and significantly associated with ROE. The finding implies that as size increases, ROE also increases. The result may suggest that size moderates the relationship between VAIC and ROE. Hence, $\mathrm{H} 1$ is supported. The regression result for model 2 exhibits that the model with $\mathrm{R}^{2}$ of 0.0189 and F-value of 1.95 (statistically insignificant), suggesting that the model is able to explain only approximately about 2 percent variation in the firms' ROE and not reliable for prediction. Thus, $\mathrm{H} 2$ is not supported.

The results show a positive moderator effect of firm size on the relationship between intellectual capital and financial performance in construction. The findings suggest that firms' value creation capability increases with firms' size, thus larger firms' are in a better position to generate profit. This could be attributed to several reasons. First, larger firms can take advantage of economy of scale by exploiting experience curve effects and setting prices above the competitive level. Second, larger firms have greater bargaining power over suppliers and customers. Third, larger firms can generate greater sales due to greater production capacity which enhances cost savings through economy of scale (Fiegen and Karnani, 1991; Ravenscraft and Scherer, 1987).

The finding supported the contingency theory, indicating that larger construction firms will be more likely to gain significant benefits in theirs' value creation capability than smaller firms, thus increasing profitability. However, firm size does not moderate the relationship between capital structure and 
financial performance. The result implies that firms' leverage decision has an equal impact on small and large firms.

\section{Conclusion and Recommendation}

The objective of this paper is to investigate the impact of firms' size on the relationships between intellectual capital, capital structure and financial performance in Malaysia construction industry. The findings of the study suggested that firm size moderates the relationship between intellectual capital and financial performance. When size increases by 1 unit, ROE increases by 26 unit. The result is consistent with the findings of Scafarto et al. (2016) which documented that larger firms have better access to resources and wealth creation through economy of scale, economy of scope and bargaining power. Contingency theory provides an appropriate theoretical framework in describing the incentive for increasing size. The relationship between intellectual capital and financial performance is contingent upon the size of the firms, whereby, the bigger the size, the more efficient the firm in managing its intellectual capital to boost performance. Thus, the results on the moderating effect of size on the relationship between intellectual capital and financial performance as revealed by the study is sufficient to contribute to the theory. On the contrary, with respect to capital structure and financial performance, firms' size, is not in line with contingency theory.

Some practical implications of the study is that manager in construction industry may consider their firms' sizes as the findings of the study suggested that the firms' value creation capability increases with firms' size, thus larger firms' are in a better position to generate profit. The managers may incorporate economy of scale, economy of scope in their corporate business strategies and exercising their bargaining power over suppliers and customers in order to increase profitability.

The sample firms were drawn from only one industry, construction, hence, it limits the generalization of the findings to other industries and the relatively narrow five-year period for the data collection are some of the limitations of the study that need to be acknowledged.

This study acknowledges that financial performance (which is a dependent variable) is a function of various factors such as corporate governance mechanism, ownership structure, age, leverage and size (Ku Ismail and Abdul Karim, 2011). Most prior studies had treated firm-specific variables (corporate governance mechanism, ownership structure, age, leverage and size) as control variables in the analyses (Ling, 2013). Firm age and firm size, for example, have been shown to vary with firm performance (Hannan and Freeman, 1984; Reed, Lubatkin and Srinivasan, 2006; Youndt, Subramaniam and Snell, 2004). Furthermore, knowledge creation and diffusion are evolutionary in nature as a result the degree to which a firm develops its intellectual capital may vary with its age (Youndt et al., 2004). Likewise, firm size may influence the development of intellectual capital through the access to resources (Serenko, Bontis and Hardie, 2007; Youndt et al., 2004). The above suggested that firm-specific variables may act as a moderator in the relationship involving firm performance. Nevertheless, this study only tested the moderating impact of firm size on profitability. Perhaps, in future study, other firm-specific variables may be examined for their moderating impact on firms' financial performance. 


\section{References}

Abbas, A., Bashir, Z., Manzuor, S. and Akram, M.N. (2013). Determinants of firm's financial performance: an empirical study on textile sector of Pakistan. Business and Economic Research, 3(2), 77-86.

Abor, J. (2005). The effect of capital structure on profitability : an empirical analysis of listed firms in Ghana. Journal of Risk Finance, 6(5), 438-447.

Addae, A.A., Nyarko-Baasi, M. and Hughes, D. (2013). The effects of capital structure on profitability of listed firms in Ghana. European Journal of Business and Management, 5(31), 215-229.

Al-Musali, M.A.K \& Ku Ismail, K.N.I (2014). Intellectual capital and its effect on financial performance of banks: Evidence from Saudi Arabia. Procedia-Social and Behavioural Sciences,164,201-207.

Betts, S.C., (2003). Contingency Theory: Science or Technology. Journal of Business \& Economics Research, 1(8), 123-129.

Daft, R. L. (1992). Organizational theory and Design, New York: West Publishing Company.

Donaldson, L., (2001). The Contingency Theory of Organizational Design: Challenges and Opportunities.

Fiegen, A. and Karnani A. (1991). Output Flexibility - A competitive advantage for small firms. Strategic Management Journal, 12, 101-114.

Frank, Z. M. and Goyal, V. K. (2003). Testing the pecking order theory of capital structure. Journal of Financial Economics, 67, 217-248.

Hannan, M. T., \& Freeman, J. H. (1984). Structural inertia and organizational change. American Sociological Review, 49: 149-164.

Joshi, M., Cahill, D., Sidhu, J. \& Kansal, M. (2013). Intellectual Capital and Financial Performance: An Evaluation of the Australian Financial Sector. Journal of Intellectual Capital, 14(2), 264-285.

Karadeniz, E., Kandir, S. Y., Balcilar, M., \& Onal, Y. B. (2009). Determinants of capital structure: Evidence from Turkish lodging firms. International Journal of Contemporary Hospitality Management, 21(5), 594-609.

Ku Ismail, K.N.I and Abdul Karim, M. (2011). Intellectual capital and financial performance of banks in Bahrain. Journal of Business Management and Accounting, 1 (1), 63-77.

Ling, Ya-Hui (2013). The influence of intellectual capital on organizational performance- Knowledge management as moderator. Asia Pac J Manag.

Marsh, P. (1982). The choice between equity and debt: An empirical study. Journal of Finance, 45, 1471-1493.

Morri, G. and Cristanziani, F. (2009). What determines the capital structure of real estate firms? Journal of Property Investment \& Finance, 27(4), 318-372.

Nirajini, A. and Priya, K. B. (2013). Impact of capital structure on financial performance of the listed trading firms in Sri Lanka. International Journal of Scientific Research Publications, 3(5), 1-9.

Pulic, A. (1998). Measuring the Performance of Intellectual Potential in Knowledge Economy. (presented in 1998 at the $2^{\text {nd }}$ McMaster World Congress on Measuring and Managing Intellectual Capital by the Austrian Team for Intellectual Potential).

Retrieved from http://www.measuringip.at/Opapers/Pulic/Vaictxt.vaictxt.html 
Ravenscraft, D.J. and Scherer, F.M. (1987). Life after takeover. Journal of Industrial Economics, 36 (2), 147-156.

Reed, K. K., Lubatkin, M., \& Srinivasan, N. (2006). Proposing and testing an intellectual capital-based view of the firm. Journal of Management Studies, 43(4), 867-893.

Salim, M. and Yadav, R. (2012). Capital structure and firm performance: evidence from Malaysian listed firms. Procedia, Social and Behaviourial Science, 65, 156 -166.

Safarova, Y. (2010). Factors that determine firm performance of New Zealand listed firms. Dissertation submitted to Auckland University of Technology.

Serenko, A., Bontis, N., \& Hardie, T. ( 2007). Organizational size and knowledge flow: A proposed theoretical link. Journal of Intellectual Capital, 8(4), 610-627.

Scafarto, V., Ricci, F. and Scafarto, F. (2016). Intellectual capital and firm performance in the global agribusiness industry: The moderating role of human capital. Journal of Intellectual Capital, $17(3), 530-552$.

Scott, W.R. (1992). Organizations: Rational, Natural, and Open Systems. Englewood Cliffs, N.J.: Prentice-Hall.

Sharma, A. and Kesner, I. (1996). Diversifying entry: some ex ante explanations for post-entry survival and growth. Journal of Finance, 39, 635-677.

Suhaila, M. K., \& Wan Mahmood, W. M. (2008). Capital structure and firm characteristics: Some evidence from Malaysian firms. http://mpra.ub.unimuenchen.de/14616/ MPRA Paper No. 14616.

Ting, I.W.K. and Lean, H.H. (2011). Capital Structure of Government-Linked Companies in Malaysia. Asian Academy of Management Journal of Accounting and Finance. Vol. 7 (2), pp. 137-156.

Youndt, M. A., Subramaniam, M., \& Snell, S. A. (2004). Intellectual capital profiles: An examination of investment and return. Journal of Management Studies, 41(2), 335-361. 